Nikita Pivovarov

\title{
What Kind of Religious Persons Were Invited to the USSR, and Who Was Allowed to Go Abroad (1943-1985)
}

Translated by Marlyn Miller

DOI: $10.22394 / 2311-3448-2017-4-2-88-112$

Nikita Yu. Pivovarov - Department of National History and Cultural Studies, I. M. Sechenov First Moscow State Medical University (Moscow, Russia).pivovarov.hist@gmail.com

This article explores the history of official "religious" travels to and from the USSR in the period of 1943 to 1985. The main sources are the documents of the Central Committee of the Communist Party. The study analyzes how the trips were prepared and realized, how and why people from various religious confessions were sent abroad and invited to the Soviet Union, and other related issues. The author distinguishes the following types of official missions: diplomatic, recreational, educational, religiousfunctional, and pilgrimage. There were three key political objectives propaganda, information, and recruitment. These trips played an important role as they established a systematic form of communication, which sometimes served as an alternative to official diplomacy.

Keywords: Central Committee of the Communist Party of the Soviet Union, the Council for Religious Affairs, the Council for the Affairs of the Russian Orthodox Church, Moscow Patriarchate, Soviet diplomacy.

7 HE goal of this article is to demonstrate the role and significance of trips along religious lines during the years of the Cold War. It will analyze only those official trips abroad by religious figures from the USSR and trips by representatives of foreign religious institutions to the Soviet Union that were discussed and approved by the highest leadership of the country, the CC RCP(b)/CPSU. ${ }^{1}$ The study of such official travel can help expand our conception of how the Soviet leader-

1. The Central Committee of the All-Russian Communist Party (Bolshevik)/Communist Party of the Soviet Union - Trans. 
ship used religious institutions in conditions of ideological confrontation in a bipolar world, and allow us to better understand how religious communication was effected between the Soviet Union and the outside world.

Researchers have repeatedly addressed the history of international church relations during the years of the Cold War. ${ }^{2}$ The most extensive analysis of official church travel is presented in the works of V. A. Akhmadulin (2013a; 2013b), O. Iu. Vasil'eva (2000, 2004), T. V. Volokitina (2003), V. A. Livtsov (2000, 2008), I. I. Maslova (2005a; 2005b), S. V. Petrov (2014), T. A. Chumachenko (1999; 2007a; 2007b; 2008a; 2008b; 2010; 2014; 2015a; 2015b), I. V. Shkuratov (2005), and V. N. Iakunin (2002a; 2002b). Certain aspects of church trips have been described in works by Iu. V. Danilets and V. V. Mishchalkin (2013), N. I. Egorova (2005), W. Sawatsky (1981), I. V. Levchenko (2001), M. I. Odintsov (1994), and D. V. Pospelovskii (1995). General works by E. Gorsuch (2011) and I. V. Orlov and A. D. Popov (2016) contain important analyses of organizational-legal questions concerning travel abroad; however, the authors' main focus was not official, but tourist travel. Despite significant historiographical groundwork, the authors devoted most of their attention to journeys by representatives of the Russian Orthodox Church during the period of "Late Stalinism" and "Khrushchev's decade." In doing so, they neither described nor analyzed organizational questions of departure abroad and the reception of foreign representatives; there are still no reasonably accurate data on the number of religious trips. The history of the foreign contacts of practically all non-Orthodox faiths has remained in the background of the historiography. But most importantly, the overwhelming majority of studies are based on material from the Council for Religious Affairs (CRA) (GARF f. R-6991), and much more rarely on sources from the archive of the Foreign Ministry. Only sporadically do publications use documents of the higher party organs.

The documents of the Central Committee apparat, in the broadest sense of the word, were key sources for this article. They included not only the departments and divisions directly supervising religious organizations, but also the Politburo (Presidium) and the Secretariat of the Central Committee. Plans for undertaking trips and upcoming invitations were the most important documents for this article, as well as records of the results of these activities. Thanks to the official record file of the General Department of the CPSU Central Committee it has prov-

2. The main historiographical problems of the external activities of the ROC can be found reflected in Korol 2013, 144-52. 
en possible to ascertain the dynamics of the number of trips for religious purposes. Unfortunately, not all sources are available to researchers today (so, for example, the data on the number of trips to the USSR can be studied only until 1980). However, an analysis of available documents allows for a much better understanding of the political meaning that the Soviet leadership attached to such international contacts.

Before the Second World War, international religious contacts in the RSFSR/USSR were practically nonexistent. The leaders of the party only considered the question of sending clergy abroad twice during the 1920 s and 1930s. ${ }^{3}$ And in both cases the trip never took place. Before the war not a single resolution about an official invitation for foreign religious figures was approved. The only visits that might be related to religious travel were those undertaken by the representatives of the "Congress of the International of Proletarian Freethinkers" and the "Council of the Union of Atheists." During the second half of the 1920 s and the first half of the 1930s, "atheists" regularly traveled abroad and came to the USSR.

In the war years the atheistic onslaught significantly weakened, and a gradual revival of church institutions began in Soviet society. It was at this time that the first official church visit to the USSR took place. Metropolitan of Kiev and Galicia Nicholas (Iarushevich) initiated it. In September 1942, while in Kuibyshev in a state of evacuation, he met with Buckley, the British ambassador's assistant, and proposed an exchange of delegations between the Russian Orthodox and Anglican churches. It is unknown whether it was an impromptu gesture of the metropolitan or proposals developed by Moscow were behind it. But in March 1943 British Ambassador Archibald Clark Kerr sent a note to V. M. Molotov with a request to accept a delegation from the Anglican church in the USSR. Six months later, in September, a small group of representatives of the Anglican Church, headed by Archbishop of York C. F. Garbett, visited Moscow. Metropolitan Nicholas represented the Orthodox Church at the meeting. This trip had extremely important implications for foreign policy. The fact of the arrival of the delegation

3. This issue was discussed for the first time at a meeting of the Politburo on September 29, 1921. Then the head of the Central Executive Committee and concurrently chairman of the Pomgol Central Committee, Kalinin announced the necessity of sending representatives of Soviet clergy to the London Congress of the Clergy. The second time the question of travel was addressed was ten years later. In the beginning of 1931, the chairman of the Standing Committee on the Question of Cults of the Central Executive Committee, P. G. Smidovich, sent I. V. Stalin a memorandum, in which he proposed sending an Orthodox delegation to London to take part in the work of the "Dogmatics Commission" in October 1931 and to the pan-Orthodox meeting on Mt. Athos in June 1932. 
to Moscow was sanctioned by a small mention in the newspaper Izvestiia - an event that was unprecedented for that time (Izvestiia no. 223, September 21, 1943).

Subsequently, the Council for the Affairs of the Russian Orthodox Church (CAROC), established in September 1943, and the Council for the Affairs of Religious Cults (CARC), formed in May 1944, oversaw questions of Church diplomacy. However, the normative documents of these councils lacked any kind of regulation to govern the foreign activities of Church organizations. ${ }^{4}$ The head of the CAROC, G. G. Karpov, had already turned his attention to this situation by 1946. In a memorandum addressed to I. V. Stalin, he wrote:

Almost three years of practice in the work of the Council on the Affairs of the Russian Orthodox Church in the Council of Ministers of the USSR has shown that its role, functions, and volume of work has significantly exceeded the limits provided for in the Statute on the Council. If in its first period the Council's activities were directed mainly toward the organizational apparatus of the Russian Orthodox Church, the expansion of its Church-patriotic activities among believers and the normalization of relations between the Church and the state, then in the subsequent period, and particularly after the end of the Great Fatherland War, the Council directed its particular attention to foreign policy work, which entailed the expansion of its spheres of activity and the influence of the Russian Orthodox Church abroad and the strengthening of its authority and relations with other autocephalous Orthodox churches around the world. (RGANI, f. 3, op. 6o, d. 1, l. 17)

In Karpov's opinion, it was necessary to strengthen the "exploitation of the Orthodox Church in the political interests of the Soviet Union" (RGANI, f. 3, op. 60, d. 1, 1. 18). Foreign trips and invitations to the Soviet Union through the Moscow Patriarchate were meant to be effective instruments for the unmasking of the "slanderous fabrications on the position of both religion and the church in the USSR" (RGANI, f. 3 , op. 60, d. 1, l. 17) that were spreading in the West and also to work on strengthening Soviet foreign expansion in the countries of Eastern Europe. Karpov suggested allocating the following areas of foreign policy to the Moscow Patriarchate (MP): to exercise influence on the ecumenical movement (mainly on the Anglican Church, and the Meth-

4. Most often, religious foreign policy measures emerged from the normative administrative order. For example, in the spring of 1945 , V. M. Molotov directed the CAROC to develop a range of foreign policy objectives for the Russian Orthodox Church. See Murashko and Odintsov 2003, 308-11. 
odist and Baptist organizations in the USA); to oppose the policy of the Vatican in the international arena (primarily dealing with the Uniate Church); to enhance work with the Evangelical Church of Germany, and finally, to overcome the "Karlovatsky Schism."

After the meeting of the heads and representatives of the autocephalous Orthodox churches in Moscow in July 1948, in connection with the celebration of the 500-year anniversary of the autocephaly of the Russian Orthodox Church, the foreign policy thrust of the Moscow Patriarchate shifted again. Now the Vatican was not the only major enemy of the Moscow Patriarchate; it was joined by the ecumenical movement in the form of the World Council of Churches (WCC). Karpov indicated the new foreign policy vectors even more clearly in a memo composed for Stalin on the results of the meeting:

Taking into consideration the positive achievement of the assigned tasks by representatives of the Church who traveled abroad in 1945-1948, and not overestimating the role and significance of the Church, the Council believes that it is possible to employ the foreign activity of the church more widely in the interests of the state. Above all it is necessary to maintain, reinforce, and implement in practice complete isolation from the West for the Orthodox churches of the countries of the people's democracy, ${ }^{6}$ securing support for the Russian church's line on their end. (Chumachenko 2008a, 68-69)

The 1955 note from the chairman of the Committee of Information of the USSR Ministry of Foreign Affairs and the deputy minister of foreign affairs Andrei Gromyko was the first document outlining the new trends in Church diplomacy in Khrushchev's time (RGANI, f. 3, op. 60, d. 29, l. 44). In it, the future minister of foreign affairs proposed that the Moscow Patriarchate not simply resume relations with the ecumenical movement,

5. The "Karlovatsky Schism" was a consequence of the decisions made at the Karlovatsky Sobor (a council of bishops at Sremski-Karlovatsky in the Kingdom of Serbs, Croats, and Slovenes) in 1921. The Council adopted the text of an appeal, "To the Children of the Russian Orthodox Church Existing in Diaspora and Exile" on the necessity of restoring the monarchy and the reigning House of Romanov in Russia, and sending an appeal to the International Peace Conference in Genoa not to recognize the Bolshevik government. Patriarch Tikhon, the Synod, and the Supreme Church Council adopted a resolution condemning the decision taken at the Council, and announced the abolition of the Supreme Ecclesiastical Administration Abroad (VTsUZ). The foreign bishops felt that Patriarch Tikhon's decisions had been dictated by Bolshevik pressure and refused to immediately liquidate VTsUZ. See Veniamin and Tishagin 2000, 10:106-8.

6. I.e., Eastern Europe - Trans. 
but become a full member of the WCC. After this note, endorsed by the Presidium of the Central Committee of the CPSU, dialogue actually began between the Moscow Patriarchate and the World Council of Churches. In 1956 the leadership of the WCC informed Metropolitan Nicholas of their unanimous decision to accept the Russian Orthodox Church into membership in the organization (Chumachenko 2010, 114). Another important document - a 1958 note from the chairman of the CARC, A. A. Puzin - proposed a significant increase in foreign trips by Muslim clergy to strengthen Soviet influence in the countries of the East. On the basis of this note, the Central Committee's Commission on Culture, Ideology, and International Party Ties adopted a resolution, "On the Expansion of Connections between Religious Organizations of the USSR and Religious Figures and Organizations of the Countries of the Near and Middle East." The state now allowed the spiritual administrations of Soviet Muslims not only to invite more representatives from Arab countries, but also to take part more actively in international Islamic gatherings. Later, the All-Union Council of Evangelical Christians-Baptists and the Estonian and Latvian Evangelical Lutheran Church received the right to more actively engage in foreign political activity.

Finally, yet another document that defined the development of the foreign activities of religious organizations during Khrushchev's time was a 1960 note by the KGB. The document proposed intensifying the ideological struggle with the Vatican, because in the opinion of the committee's leaders, the papal throne "keeps Western diplomacy on a ColdWar footing by every means possible and interferes with the alleviation of tension in international relations" (RGANI, f. 3, op. 60, d. 29, 1. 44). The note proposed to undermine the authority of the Vatican by strengthening the role and significance of the Prague Christian Peace Conference, to engage the Anglican and Evangelical Lutheran churches in its work, and to improve relations with the Ecumenical, Alexandria, and Jerusalem patriarchs. It also proposed facilitating the organization of meetings and conferences of religious associations in various countries of the world in every way possible, at which they would concurrently discuss questions of peace and the friendship of peoples, and develop anti-Vatican sentiment. The KGB's note was the basis for the Presidium of the Central Committee's top-secret decree (it was stamped "special folder"), "On Strengthening the Work against the Vatican and Expanding the External Activities of the Religious Centers of the USSR in the Struggle for Peace," which reflected all the proposals of the KGB.

The resolution of the Secretariat of the Central Committee, "On the Development of Relations between the Moscow Patriarchate and the 
Churches of Africa" was the first of Brezhnev's initiatives, adopted in May 1965. After the merger of the councils into a single Council for Religious Affairs (CRA) in late 1965, the leading role of the new entity in the organization of the external activities of church institutions was finally fixed in its legal statute. Beginning in 1967, the Council generated and submitted plans to the Secretariat of the CC CPSU for trips and invitations along religious lines. ${ }^{7}$ Now only unscheduled trips were separately approved in the $\mathrm{CC}$, and the number of these was insignificant. This was the practice until 1990. After 1990, the CC CPSU ceased regulating all foreign travel and visits to the USSR.

Meetings of the Secretariat of the CC and/or the Politburo (Presidium) of the CC reviewed and approved issues related to religious travel directly within the Central Committee. From 1959, the Commission of the Central Committee on Culture, Ideology, and International Party Ties, headed by M. A. Suslov, managed questions of travel. After its abolition in 1962 and up until 1990, the Secretariat of the CC approved all resolutions (with the exception of certain cases, such as the trip in 1983-1984 by the American Evangelical preacher Billy Graham, which the Politburo authorized).

Before they made it to the table of the Politburo members or the secretaries of the Central Committee, documents about trips abroad or invitations to the Soviet Union passed through a long process of approval. ${ }^{8}$ Formally, all invitations to the USSR issued from religious organizations, the Soviet Committee in Defense of Peace or Soviet friendship societies. But it was the head of the CAROC, the CARC, or the CRA who dispatched the initiating memorandum to the CC (as a rule, with a draft of the $\mathrm{CC}$ resolution). After receiving the documents, employees of the Special Sector (from December 1952 to March 1953, part of the Office of the Presidium of the CC, from March 1953 to August 1991, part of the General Department of the Central Committee) forwarded them to multiple addresses. In 1944-1947, materials arrived at the Commission of the CC CPSU(b) on Trips Abroad, from 1947 to 1949 - at the Bureau on Trips Abroad and Entries into the USSR of the Committee of Information of the Council of Ministers of the USSR, the work of which was directly supervised by L. P. Beria, in

7. The first plan for travel abroad and invitations to the USSR for religious purposes was approved under Stalin. In 1949 the Politburo approved a plan for 1950; however, this administrative innovation did not catch on, and travel planning ceased from 1951.

8. In 1959, the leaders of the CAROC and the CARC sent a proposal to the Central Committee for elaborating uniform principles for invitations and for sending clergy abroad. However, the secretariat of the CC did not approve the project. 
those years a candidate member (from 1946, a member) of the Politburo and deputy chairman of the Council of Ministers of the USSR. Corrections and recommendations from L. P Beria and I. V. Stalin are often found on accompanying notes and draft regulations prepared by the chairmen of the Councils, G. G. Karpov and I. V. Poliansky.

From 1949, the Foreign Affairs Commission of the Central Committee of the All-Union Communist Party (Bolshevik) (from October 1952 to March 1953, the Commission of the CC CPSU on Relations with Foreign Communist Parties), headed by V. G. Grigorian, managed all foreign church contacts, along with the reestablished Commission on Trips Abroad of the Central Committee of the All-Russian Communist Party (Bolshevik)/CPSU. ${ }^{9}$ V. M. Molotov supervised the activity of the commission from 1949 to 1953. At the same time, V. G. Grigorian and K. E. Voroshilov coordinated certain issues of religious trips abroad. After Stalin's death the Commission was abolished, and its functions were transferred to the Department of the Central Committee on Relations with Foreign Communist Parties. In February 1957 the department was split into the International Department on Relations with Communist Parties of the Capitalist Countries (from 1971, the International Division), and the Department of the CC CPSU on Relations with Communist and Workers' Parties of Socialist Countries. These two structural units also directly managed all church trips and visits to the USSR. Additionally, within the Central Committee the issue of travel might be considered by the Department of Administrative Organs, the Department of Agitation and Propaganda, or the Information Department, but the International Department and the Department on Socialist Countries retained the final say.

Besides the Central Committee, the question of travel had to be negotiated with the Ministry of Foreign Affairs. From the 1950s, together with the departments of the ministry, the ambassador of the country to or from which a delegation was traveling presented his own opinion on specific issues. In very rare cases, the CAROC or CARC (CRA) invited religious figures to acquire additional information or a personal opinion from them. Some documents reflect all the bureaucratic peripeteia

9. In December 1962, the Commission was abolished and its functions transferred to the Department of Personnel for the Diplomatic and Foreign Trade Agencies of the Central Committee of the CPSU (from May 1965, the Department of Foreign Personnel of the CC CPSU). In January 1967, a Commission on Travel Abroad within the CC CPSU was again created based on the Sector for Travel Abroad of the Department. In March 1973, the Department and Commission were united in one structural division - the Department for Work with Foreign Personnel and Travel Abroad. This structure survived until 1990. 
of preparing church travel. For example, in 1955 the Department of the $\mathrm{CC}$ on Relations with Foreign Communist Parties, the German sector of the Ministry of Foreign Affairs, the Soviet embassy in the GDR and Metropolitan Nicholas (Iarushevich) all took part in the negotiation of a trip by a delegation of the Russian Orthodox Church to the Rhineland.

The organs of state security were another key authority that made decisions on religious travel. In the period of late Stalinism the opinion of these organs was of decisive significance. For example, in 1948 the leadership of the CARC approved a visit of Soviet rabbis to Poland to take part in a commemoration of the five-year anniversary of the Warsaw Ghetto Uprising. However, the leadership of the MGB opposed the trip, and it was postponed (RGANI, f. 3, op. 6o, d. 27, 1. 165). In 1952 the Ministry of Foreign Affairs and the Foreign Policy Commission of the CC of the All-Union Communist Party (Bolshevik) insisted that during his trip to the Soviet Union, the head of the Evangelical Lutheran Church of Hesse, Pastor Martin Niemöller, could familiarize himself with the life of German and Austrian prisoners of war and internees. The leadership of the MGB opposed this, since in the opinion of the security officers the prisoners of war might say unflattering things about the Soviet Union (RGANI, f. 3, op. 60, d. 27, l. 128). The Politburo CC heeded this opinion and recommended insulating the German pastor from additional contacts.

Representatives of religious institutions most often traveled abroad as part of a delegation. Officers of the NKGB (MGB) and later the KGB accompanied church hierarchs in the guise of assistants, interpreters, and security guards. Their main task consisted of protecting the Soviet religious figures, since some trips presented real, mortal danger. For example, in the course of Patriarch Alexy's visit to Syria in 1945, armed clashes between Syrian rebels and French occupying forces suddenly broke out, and only thanks to the coordinated efforts of the NKGB officers were the patriarch and his entourage safely removed from the conflict zone. But along with protection, the officers of the security services collected information on the host country and most importantly attentively followed about what and to whom the Soviet church leaders spoke. For a short interval after the death of Stalin (until about the middle of the 1950s), they allowed religious figures to travel without an escort. When A. V. Karev, secretary of the All-Union Council of Evangelical Christians-Baptists (ACECB), went to Norway alone in 1954, the local religious leaders were surprised that there was no "translator-squealer" along with him. The Norwegians considered this an indication of political changes in the Soviet Union, but after 
the creation of the KGB the trips with escorts resumed (RGANI, f. 3, op. 6o, d. 28, 1. 120).

Who was allowed to go abroad? Trusted religious leaders, whose loyalty to the Soviet Union was not in doubt. As a rule, they were Church administrators or direct leaders of churches (patriarchs, leaders of the ACECB and evangelists, heads of Muslim and Buddhist spiritual administrations, and so on), or those responsible for external relations. In the Russian Orthodox Church, Patriarchs Alexy and Pimen, Metropolitan Nicholas (Iarushevich), Nikodim (Rotov), Alexy (Ridiger); in the ACECB, president of the council Ia. A. Kidkov, secretary of the council A. V. Karev; in the Evangelical Lutheran Churches of Latvia and Estonia, Archbishop Jaan Kiivit and Gustav Tūrs; of the Muslims - the chairman of the Spiritual Administration of the Muslims of Central Asia and Kazakhstan, Mufti Z. Babakhanov.

Loyalty to Soviet power was important, but was not always the determining criterion for the selection. No less important were diplomatic skills, and most important, oratorical abilities. This was particularly vital for church travel in the years during and immediately after the war. Metropolitan Nicholas (Iarushevich) was an outstanding diplomat and orator. He communicated easily both with representatives of the Western world and with the heads of the Eastern Orthodox churches. His sermons had a great influence on Russian emigrants in France, England, and Finland. In reports for Stalin about Metropolitan Nicholas's trips to Western Europe, G. G. Karpov said that he had been received enthusiastically in London by the princes Golitsyn and Obolensky, and in Paris by Grand Duke Andrei Vladimirovich, Prince P. A. Obolensky, and a number of Russian professors. His sermons were repeatedly interrupted by exclamations: "take us home with you to the motherland," "kiss our native earth," "bow to the earth for the Russian people" (RGANI, f. 3, op. 6o, d. 27, 1. 111). This is how Karpov described the atmosphere in one of the London Orthodox churches during the metropolitan's sermon: "Metropolitan Nicholas's address made a strong impression on those present in the church; they listened avidly, and many wept; departing from the church they shared impressions, embraced, and offered Eastertide congratulations; they said that many spoke of it as a revelation" (RGANI, f. 3, op. 60, d. 27, 1. 101). Travel to Western countries was allowed for Metropolitan Nicholas, a journey that, particularly in Stalin's time, was closed even to Patriarch Alexy.

The state regulated visits of foreign religious figures to the USSR even more closely than trips abroad. Before he was given a permit for 
entry into the Soviet Union, a detailed profile was compiled on the future guest that described his political views, writings, and private statements. The authorities collected and studied data on Muslims from Arab countries and Christian leaders from Western Europe and America with particular care. For decades the same trusted church leaders came to the Soviet Union - "friends of the Soviet regime." The foreign guests' schedule for their stay in the Soviet Union was carefully designed. In addition to interchurch fellowship (holding shared worship services) and the display of religious objects, tours showed the guests the secular achievements of the Soviet Union. Thus, upon first visiting the USSR, they showed the delegation of the Bulgarian Orthodox Church the State Historical Museum, the Museum of Serf Art at Ostankino, the Tretyakov Gallery, the Moscow Metro and the Moscow River Terminal, and also showed the play Tsar Fyodor Ivanovich at the Moscow Art Theater (RGANI, f. 3, op. 60, d. 30, 1. 22). ${ }^{10}$ Several delegations traveled to Leningrad, Kiev, Kazan, and Tbilisi in addition to Moscow. Sometimes the foreign guests themselves expressed the desire to visit secular premises. For example, during the visit of Serbian patriarch Vikentije II to the USSR in 1956, members of his delegation appealed to G. G. Karpov with the following request: "We also have many churches; we want to see one or two factories, hospitals and children's facilities, sovkhozes and kolkhozes, and your culture in Leningrad, Kiev, and Moscow" (RGANI, f. 3, op. 60, d. 30, 1. 102). During a return visit they promised to show the patriarch of Moscow a power station, a shipyard, and five to six factories. Sometimes the authorities organized formal dinners and receptions at the Council of Ministers or the Supreme Soviet of the USSR in honor of foreign delegations.

During these visits there was an exchange of gifts. For example, in accordance with a decree of the Soviet Council of Ministers, the state presented the patriarch of Antioch with a Palekh box with a view of the Kremlin and a silver liqueur service on the occasion of his visit to the USSR in 1951, and during a visit in 1954 the Antioch primate received a gift from the patriarch of Moscow on his saint's day - a box with ten thousand dollars (RGANI, f. 3, op. 60, d. 30, 1. 38). The value of the gifts depended on the "value" of the guest. In 1956, the Presidium of the Central Committee of the CPSU decided to bestow gifts

10. The tradition of showing Soviet theatre to religious guests arose during the first trips. Canon F. House, who took part in the meeting of the representatives of the Anglican Church with the leaders of the Moscow Patriarchate in 1943, recalled that in the evening, after the official talks, the English delegation was invited to the opera Eugene Onegin (House 1983). 
on the secretary of the Commission for Religious Affairs of Yugoslavia M. Dilparic and his family up to the value of two thousand rubles with the wording "taking into account the special nature of our relations with Yugoslavia” (RGANI, f. 3, op. 60, d. 30, 1. 102), while the Serb patriarch Vikentije, who formally headed the Yugoslav delegation, received "only" a gold panagia. In 1956, not only did the Soviets arrange an invited dinner for Metropolitan of Beirut Elias (Saliba), as he was one of the probable candidates for the post of patriarch of Antioch, but they also handed over fifteen thousand dollars in Lebanese currency as a gift (Chumachenko 2010, 111). Some guests brought gifts with them. For example, in 1951 the patriarch of Antioch gave G. G. Karpov a camel hair coat and a handworked cloth (RGANI, f. 3, op, 6o, d. 30, l. 103), and in 1954 he awarded the chairman of the CAROC the Order of the Apostles Peter and Paul, the highest award of the Antiochian church.

The dynamics of the number of journeys by religious figures and their corresponding geography make it possible to draw conclusions about those who went abroad most often: representatives of the Russian Orthodox Church (an average of twenty trips per year), of the Evangelical Lutheran Churches of Latvia and Estonia (an average of six trips per year), of the ACECB (an average of five trips per year), and of the Armenian Apostolic Church (an average of four trips per year). The ROC was also a "record holder" by another metric: it was the only confession whose representatives went abroad annually throughout the Cold War. But representatives of Jewish organizations were the absolute "outsiders" with regard to trips abroad. The Secretariat of the $\mathrm{CC}$ twice adopted a resolution forbidding the departure of Moscow rabbis abroad (in 1948 and 1959), and over the course of forty years only once (in 1957) did it allow Soviet Jews to attend a foreign event.

On the whole, it is possible to suggest the following periodization for travels of Soviet religious figures abroad. The first period (19451953) falls during the time of "late Stalinism." During that time, they mainly sent abroad only representatives of the Russian Orthodox Church. The geography of these trips also did not vary in terms of latitude. If in 1945-1946 representatives of religious organizations in the USSR still undertook trips to Western countries (England, the USA, France), after 1947 this practice waned. The countries of Eastern Europe became the chief destinations. The second period (1953/1954 to the end of the 1950s) occurred in Khrushchev's first years, when the state allowed representatives of many more confessions to travel abroad. Under N. S. Khrushchev, representatives of non-Christian 
faiths were sent abroad for the first time, although the geography of the host countries did not expand significantly. They went mainly to Eastern and Western Europe and the United States. The third period (the 1960s) was marked by a significant broadening of the geography of travel. Soviet religious figures "discovered" Africa for themselves, as well as Latin America and Asia. The number of trips significantly increased. The fourth period (the 1970s) fell during the period of "détente," and was marked by a quantitative increase in trips. For example, no fewer than between 36 and 48 delegations of the Russian Orthodox Church traveled yearly during this time. The fifth period (1980 to 1985) occurred during a new deterioration of relations with the West. The number of trips decreased, and religious figures began to travel less often to Western Europe and the United States.

The foreign religious figures who traveled most often to the USSR were representatives of the Anglican Church, of the patriarchate of Antioch, of the Baptist World Alliance, the Romanian and Serbian Orthodox Churches, Syrian Muslims, the World Council of Churches, and also the heads of the Secretariat (Department) for the Affairs of Religious Cults of the Council of Ministers of Czechoslovakia. Unlike with departures from the USSR, demonstrating a unified periodization in relation to travel to the USSR is practically impossible. However, it is clear that after the death of Stalin, the number of religious trips to the USSR significantly increased.

Foreign travel and visits to the USSR had diverse goals, and the religious element in them was far from the only one. The promotion of Soviet foreign policy was an important objective. Depending on the prevalence of political goals, it is possible to identify several types of official religious trips abroad - diplomatic, recreational, functionalreligious, educational, and pilgrimage. The same types can be highlighted in relation to visits to the USSR by foreign religious figures. The exception is the absence of trips of the pilgrimage type among official trips to the Soviet Union. If visitors undertook pilgrimages in the Soviet Union, they did so in private. Only one such case has been identified, in which the Secretariat of the CC CPSU approved an invitation for a group of Catholic Latvian emigrant pilgrims in 1969.

The diplomatic type of official religious trip was the most common. Often these trips were quite secular in content. For example, during a trip in 1952, Pastor Martin Niemöller of the Evangelical Church in Germany attempted to solve the problem of German and Austrian prisoners of war and internees (RGANI, f. 3, op. 60, d. 30, l. 128), while in 1954 archbishop of Nigeria Lukos conducted talks with Soviet foreign policy 
agencies on the formation of trade relations between Nigeria and the USSR (which at that time was still a British colony). The archbishop was able to reach an agreement on supplying African agricultural products to the Soviet market, including rubber, coffee, black pepper, ginger, peanut, cow hides, and cacao oil. These would be exchanged to procure Soviet industrial products such as cars and trucks, cots, men's and women's underwear, typewriters, medicine, glasswear, and so on (RGANI, f. 3, op. 60, d. 31, 1. 24). They even bypassed Britain and established a firm to trade with the Soviet Union, with offices in London and Amsterdam.

Visitors conducted meetings and negotiations at the highest political level during the course of diplomatic visits. This practice developed during the very first trips abroad. For example, during his first trip to England in 1945, Metropolitan Nicholas met with King George, members of Parliament, and also with the wife of Winston Churchill. Also in 1945, during his Middle East tour, Patriarch Alexy communicated with King Farouk of Egypt, the Greek crown prince Paul and Prince Peter, the presidents of the Lebanese and Syrian republics, and a wide range of political and public figures. In Egypt the patriarch conversed with the former prime minister of Greece, Sofoklis Venizelos, who suggested that the patriarch act as mediator for the normalization of relations between Greece and the USSR (RGANI, f. 3, op. 60, d. 27, l. 102-102ob.).

Under Stalin, foreign religious figures wanting to meet with Soviet officials could expect to communicate only with the chairmen of the CAROC or the CARC. The situation changed under Khrushchev, when the practice of negotiations between foreign church figures and senior Soviet state and party leaders developed. The first such meeting, between Serbian Patriarch Vikentije and the chairman of the Council of Ministers Nikolai Bulganin, took place in 1956 (Chumachenko 2010, 109). Its background is remarkable. In the course of preparing for a trip to the Soviet Union, the secretary of the Commission on Religious Affairs of the Federal Executive Veche M. Dilparic, in conversation with G. G. Karpov, asked which officials would receive Patriarch Vikentije. Hearing that it would be Karpov alone, Dilparic declared: "We have just now hosted the Greek archibishop Dorofei, and he was received by Tito, Ranković, etc. Will the government not receive our delegation?” (RGANI, f. 3, op. 60, d. 30, l. 101). After this conversation Karpov sent a memorandum to the Central Committee, in which he suggested that one of the Soviet leaders meet with the patriarch. On the basis of this note, the Presidium of the Central Committee adopted a resolution on a meeting between Bulganin and Vikentije. Thereafter, chairmen of the Supreme Soviet of the USSR and chairmen and 
deputy chairmen of the Council of Ministers of the USSR met with the heads of churches.

In terms of character, goals, and objectives, recreational trips were similar to the diplomatic type, but unlike them, they were used to resolve the most delicate issues that were not widely publicized. For example, in 1951 S. K. Belyshev, the first deputy of the CAROC, went to Czechoslovakia for the final suppression of the Uniates and to develop additional measures for the creation of a Czechoslovak autocephalous Orthodox church. The state attached private status to the trip, which Belyshev ostensibly undertook to receive treatment at Karlovy Vary (Chumachenko 2008a, 72). When on holiday, the primate of the Church of Antioch regularly visited the patriarch of Moscow at his residence near Odessa. ${ }^{11}$ Alexander III himself once characterized their trips to the Soviet Union for treatment thus: "At 82 years old, I'm not on vacation, and I do not need any special treatment, but I was required to propose treatment and a prolonged stay as a pretext, in order to obtain the Synod's approval to travel to the USSR" (RGANI, f. 3, op. 60, d. 27, 1. 102). The first visit of the patriarch of Antioch occurred in 1951 and was complicated by a minor diplomatic scandal. Rich Orthodox Arabs had invited the patriarch to Brazil, along with his invitation to the USSR. Karpov and the staff of the MGB believed that the British intelligence services were behind this invitation. The Soviet mission in Lebanon had to exert considerable effort so that Alexander III would finally go to the USSR, not Brazil (RGANI, f. 3, op. 60, d. 27, 1. 77).

The second most common trips were those of the functional-religious type. To this category belonged trips connected with the provision of liturgical rites such as enthronement, the consecration of churches, and burial. For example, from the mid-1950s, representatives of foreign parishes of the Armenian church regularly traveled to the residence of the supreme patriarch and catholicos of all Armenians in Etchmiadzin (Vagharshapat) to take part in the rite of the preparation of chrism. As a rule, the preparation of chrism happened every seven years. The Council of Bishops of the Armenian Church, which deliberated and made decisions on major issues, occurred at the same time. For example, in 1954 the Council discussed and approved the new constitution for the Armenian Apostolic Church (RGANI, f. 3, op. 6o, d. 20, 1. 1).

Those who left for permanent or temporary service in foreign countries constituted a special category. These were primarily priests of the

11. From 1957, they even began to give him a personal dacha in Sochi along with special care and treatment. 
Russian Orthodox or Armenian churches, or Orthodox monks bound for monasteries on Mount Athos or in Israel/Palestine. The priests were carefully chosen through consultation with advisors of the ambassador and the attaché for culture and religious ties of the country to which they were sent. For example, Soviet diplomats in Syria advised sending an archimandrite to the metochion of the Russian Church in Beirut who was fluent in French and "capable of providing for the maintenance of the prestige of the Russian Orthodox Church," that is, he needed to provide a car, expensive clothing, and spacious and opulent housing (RGANI, f. 3, op. 60, d. 28, 1. 57). Until the end of the 1950s, the Russian Orthodox Church dispatched priests and their families to Europe and the Middle East for a period of five years or more. Due to financial considerations, from the beginning of the 1960 s the Moscow Patriarchate began to send primarily priest-monks into service. As a rule, individual clerics were sent abroad, but there were also exceptions. For example, in 1956 the Patriarchate sent twenty-five Orthodox priests to Czechoslovakia at the same time for service in the Orthodox parishes of Slovakia and to counter the activities of the Uniates.

It was quite rare for foreign religious figures to visit the Soviet Union in order to conduct religious services. Most often it was Orthodox priest-emigrants who traveled and relocated to the USSR. The largest such move occurred in 1957, when after the Novo-Valaam Spaso-Preobrazhensky Monastery was transferred to the jurisdiction of the Finnish Orthodox Church in the Soviet Union, the Uspensky Pskovo-Pechersky Monastery relocated about ten monks. The adoption of compulsory Soviet citizenship accompanied all such transfers. ${ }^{12}$ It is noteworthy that until the end of the 1950s, the Central Committee registered even shortterm cases of residency by foreign religious figures in the Soviet Union. For example, when in December 1960 Bishop George Ernest Ingle arrived at the British Embassy to conduct the Christmas service, members of the Politburo were immediately briefed about this fact.

Educational trips were rarer than diplomatic or functional-religious ones. These included trips for study or to give lectures or academic seminars. Of Soviet religious organizations, those that most often sent their representatives for study abroad were the Muslim organizations - to the Academy of Islam in Cairo $(1954,1959)$; the ACECB - to the London Baptist College (1956, 1967); and the Evangelical Lutheran Church in Latvia and Estonia - to the theological faculties of Oxford Universi-

12. I also do not consider the resettlement of Dukhobors from Canada to the USSR, which began in 1958 , as travel. 
ty $(1958,1959)$ and Göttingen University (1960). From 1966, the Moscow Patriarchate annually sent future priests to study at the Ecumenical Institute at Bossey (the religious academic institution of the World Council of Churches). In 1969, the secretariat of the Central Committee adopted a resolution in accordance with which twenty-two people annually were to be sent for study from the Russian Orthodox Church, the ACECB, the Evangelical Lutheran Churches of Latvia and Estonia, and the spiritual administrations of the Muslims and the Buddhists. Representatives of the Antioch Orthodox Church and the ancient Oriental (non-Chalcedonian) churches traveled to the Moscow Theological Seminary and Academy in the Soviet Union for study.

Finally, pilgrimage trips were the rarest type. The first pilgrimage approved by the Central Committee happened in 1953. It was the Muslim hajj on the holiday of Kurban Bayram (Eid al-Adha) in Mecca and Medina (Akhmadulin 2013b, 89-91). In subsequent years these trips became an annual event, and from 1968 Shi'ia Muslims began to travel each year to memorial events in Mashhad, Iran. ${ }^{13}$ The possibility for Orthodox pilgrims to travel abroad developed only in 1964. At first Athos was the only place pilgrimage was allowed; then from 1970 Orthodox pilgrims were allowed to visit Rome. It wasn't until 1975 that the Moscow Patriarchate was able to send pilgrims to Jerusalem and other holy places in Israel/Palestine. Otherwise unremarkable pilgrimages sometimes played a very important political role. For example, the head of the CARC, A. A. Puzin, composed a note proposing to increase the number of foreign trips by Muslim clergy and to strengthen Soviet influence in the countries of the East based on data obtained in the course of pilgrimages to Mecca and Medina. But of all the pilgrimages, it is perhaps particularly worth highlighting the trip of a group of Soviet Catholics to Italy in 1957. This ordinary event was filled with important political content. The Presidium of the $\mathrm{CC}$ even adopted a resolution in connection with the trip, "On the Trip to Italy of a Group of Catholic Believers from among the Citizens of the USSR" (RGANI, f. 3, op. 60, d. 29, 1. 49). The trip was assigned an informal, private status, but its goal was to increase contacts with the Vatican. Therefore, it was organized through Intourist rather than through the CARC. All the participants were instructed how to behave abroad. They were only allowed to converse with Italian Catholics on the Soviet Union's pro-peace policy. They could respond positively about Pope Pius XII's message condemning war and the use of

13. The location of the shrine and mausoleum of Imam Reza, the eighth of the twelve Shi'ite imams. - Trans. 
weapons of mass destruction, but to the question of the normalization of relations between the USSR and the Vatican, members of the group were to answer that they were only tourists, although they believed that it would be possible under certain conditions.

The representatives of the various churches who took part in religious trips abroad carried out the orders of the state. At minimum three key political objectives can be identified, namely agitation-propaganda (image-building), information-gathering, and recruitment. The formation of an attractive image of the USSR was the basis of the image-building objective. The entities that needed to be influenced changed depending on the goals of the trip and the direction of Soviet foreign policy. For example, in the first postwar years the Soviet Orthodox clergy paid particular attention to indoctrinating Russian emigrants. In one of his reports to the CAROC, G. G. Karpov disclosed that Russian clergy in particular played a prominent role in the adoption of Soviet citizenship by large numbers of former emigrants. At the turn of the 1960s-1970s, the number, and also the geographic scope of trips by representatives of the ACECB significantly increased. These trips were designed to create a "correct understanding" within the global Baptist movement of the actions of the Soviet authorities in connection with the effective defeat of the Council of Churches of Evangelical Christians-Baptists. From the beginning of the eighties, many more Muslims began to travel abroad, which was directly connected with the war in Afghanistan.

Trips to the USSR served to strengthen the authority of foreign church figures. The patriarch of Antioch repeatedly emphasized that each of his visits to the Soviet Union raised his standing not only in the eyes of his flock, but also among the local Arab population. The visits of Soviet church delegations at the invitation of foreign churches of one or another country can also be regarded as one of the ways to strengthen the authority of the church. Thus, after the Orthodox delegation's first trip to England in 1945, Karpov reported about the Anglican church:

The mood of the leaders of the Anglican Church today: the solemnity and exceptional cordiality of the welcome extended to the Russian Church delegation, the complete absence of any hint of a patronizing attitude from the leaders of the Anglican Church toward the Russian Church in conversations with the delegation to some extent indicate that the Archbishop of Canterbury is now seeking support for himself and his church from the Russian Church, and that he wants to strengthen the influence of the Anglican Church at home through friendship with the Russian Church. (RGANI, f. 3, op. 6o, d. 27, 1. 99) 
The Soviet authorities interpreted similarly the 1955 request of the Evangelical Church of West Germany to send them a delegation from the Russian Orthodox Church. The leadership of the Department of the $\mathrm{CC}$ on Relations with Foreign Communist Parties considered the trip "of a delegation of the Russian Orthodox Church to West Germany advisable, since it will promote the strengthening of the position of the Evangelical Church in the struggle against the remilitarization of West Germany and against the division of Germany" (RGANI, f. 3, op. 60, d. $28,1.132$ ).

The task of information-gathering included the collection of the most varied data, not only about religious institutions, but about the host country as a whole, and the political, economic, and social situation. Members of the delegation presented this material, as a rule already in summary form, in reports and accounts on the results of the visits. Accordingly, one of the first accounts to the CAROC reported: "In becoming acquainted with the church situation in the Middle East, Patriarch Alexy and those accompanying him were able to notice that the British are interested in the affairs of the Orthodox Church in the Middle East, and that they exert their influence on a number of figures from the Orthodox Church" (RGANI, f. 3, op. 60, d. 27, 1. 99). But the information about the leaders of the churches and the religious institutions in foreign states should be recognized as especially valuable. Here is but a small passage from the 1950 report, composed to summarize the visit of the Orthodox delegation to the Middle East, which presents a short, but sufficiently comprehensive, characterization of the leaders of the Antioch church:

Head of the delegation Metropolitan Gregory and Protopresbyter N. F. Kolchinskii describe Metropolitan Athanasius (Arab), who at one time graduated from the Kiev Spiritual Academy, as dedicated to the Russian Church. However, Archbishop Germogen claims that Metropolitan Athanasius "will be unlikely to fight for us." . . . Metropolitan Ilya Karam (Arab) is characterized by the delegation as a zealous supporter of the Russian Church, but connected with Catholics and opponents of the Moscow Patriarchate, and when the delegation gave him a strong reprimand, he began to defend these connections of his as purely "out of Christian love.” ... Metropolitan Theodosius (Arab) is characterized as an intellectual and a highly educated man, who wavers between supporters and opponents of the Russian Church. . . . Metropolitan of Beirut Ilya Saliba (Arab) is known as a major landowner, indiscriminate in his actions, who has substantial connections in government circles, and who is referred to as an American intelligence 
operative. . . Metropolitan Hamaskii Ignatius (Arab) of Aleppo and Iyla Maun (Arab) resided for a long time in America and are fierce opponents of the Russian Church. (RGANI, f. 3, op. 6o, d. 28, 1. 55)

We only have indirect sources at our disposal to show that the representatives of foreign church institutions engaged in collecting information while in the USSR. As a rule, these are briefing notes of the Soviet embassies about their conversations that were distributed among church figures after travel in the USSR, as well as the written comments of the members of the delegations. These documents describe positive or even enthusiastic impressions produced in foreigners by their trip to the Soviet Union. For example, the head of the Bulgarian church, Metropolitan Stefan, after a meeting of the heads and representatives of the autocephalous Orthodox churches in Moscow in 1948 and a trip to Georgia, shared these plans with his inner circle: "In Georgia, the idea came to me to write a book about Stalin. I have been nurturing this thought over these two days and I will absolutely write it as soon as possible. The theme of the book is this: Stalin is truly a genius and a beacon for all peoples searching for truth, peace, and true mutual brotherly love. Oh, this is a great idea!" (Chumachenko 2007b, 94). For the whole period under consideration, I have discovered only one negative comment recorded in the Soviet documents. After the Moscow meeting in 1948, Metropolitan Iosif Skopliansky of the Serbian church declared that all the secular postwar landmarks of Moscow were built on the blood and suffering of the people (RGANI, f. 3 , op. 6o, d. 28, l. 56).

Recruiting or soliciting foreign religious figures to cooperate was one of the most important objectives of the journey. Travelers tackled it by various means: through simple negotiations and through financial instruments. In the early postwar years, the Moscow Patriarchate provided financial help to practically all the autocephalous Eastern European Orthodox churches and Eastern patriarchs. The amounts of assistance required were negotiated during these bilateral trips, and sometimes Soviet religious figures brought the money with them. For example, in 1945 Metropolitan Nicholas tried to meet with Ecumenical Patriarch Maxim to give him a gift from Patriarch Alexy - 50,000 dollars. However, the Turkish authorities refused to grant a visa to the metropolitan (RGANI, f. 3, op. 6o, d. 28, 1. 58). Metropolitan Stefan of Sophia was one of the first to receive quite substantial financial support. In 1946, he appealed to Patriarch Alexy with a request to give him 30 million lev for a term of ten years. G. G. Karpov suggest- 
ed granting about half the sum. Stalin saved the situation. In the margins of Karpov's note he made the following comment: "On the contrary. You can give even more than 30 million lev" (RGANI, f. 3, op. 6o, d. 5 , l. 115). In the end, the Bulgarian Church received 50 million lev (2.5 million rubles). Under Khrushchev (at least until the beginning of the 1960s), the Moscow Patriarchate transferred from ten to twenty thousand dollars annually to the patriarch of Alexandria, in accordance with the decision of the Presidium of the CC of the CPSU from May 9, 1955 (Chumachenko 2010, 109). ${ }^{14}$ In 1957, I. A. Serov, the head of the KGB, suggested allotting 200,000 rubles to the locum tenens of the catholicate of Cilicia of the Armenian Apostolic Church, Archbishop Kh. Achapagian, to bribe influential people in Syria and to organize propaganda against the Dashnaks. ${ }^{15}$ Such generous gifts doubtlessly contributed to the strengthening of ties between Soviet and foreign religious figures. It should be noted documentation concerning the recruitment of Soviet religious figures has not been discovered.

Severe ideological confrontation and limits on contact with the outside world, although they significantly complicated contact on a religious basis in the years of Soviet power, did not sever it entirely. On the contrary, from the end of the Second World War and throughout the Cold War, Soviet diplomacy consistently and rather pragmatically used the representatives of Soviet and foreign religious institutions in an information war against the bourgeois and capitalist world. Trips occupied a central place in the new religious diplomacy, thanks to which not only did the participation of the Soviet side in international religious organizations notably intensify, but also, a regular system of communication developed, which sometimes served as a sort of alternative to official Soviet diplomacy. However, during the course of the entire Cold War, not one of these Soviet religious figures showed themselves to be independent figures in the international arena. Foreign religious figures arriving in the USSR were, as a rule, limited in contacts and opportunities, since their trips proceeded under constant control. In general, official religious trips abroad or to the USSR should be acknowledged as a special kind of diplomatic tool, which the party-state leadership of the country used to attain their foreign policy objectives.

14. However, by 1957 the allocation of funds to the church of Alexandria was considered inappropriate. See Chumachenko 2010, 121.

15. An Armenian political party professing Armenian nationalism and democratic socialism. - Trans. 


\section{Appendices}

Table 1. Number of trips abroad by representatives of religious organizations (1945-1985)

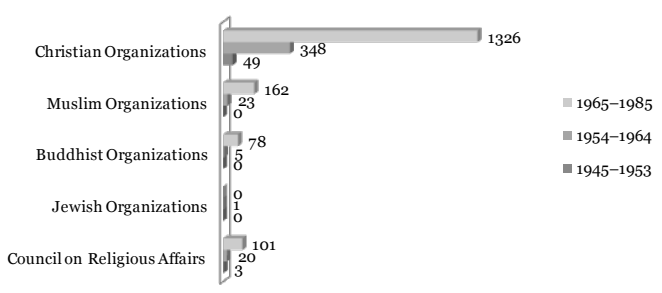

Table 2. Number of trips abroad by representatives of Christian denominations (1945-1985)

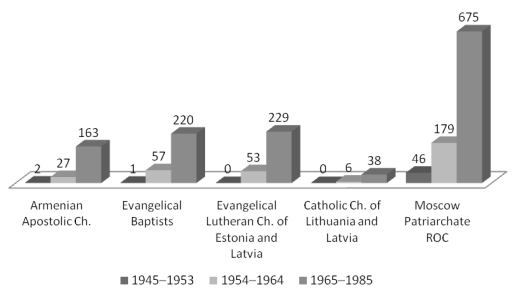

Table 3. Number of trips abroad by representatives of religious organizations (According to region of visit)

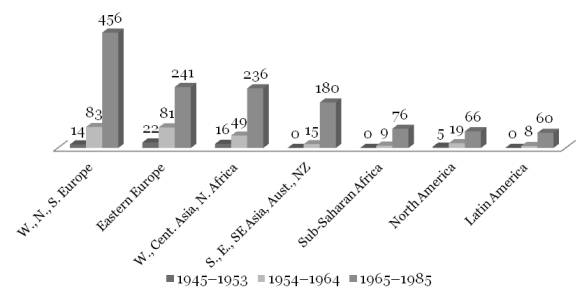

Table 4. Number of trips to the USSR by representatives of religious organizations (1943-1980)

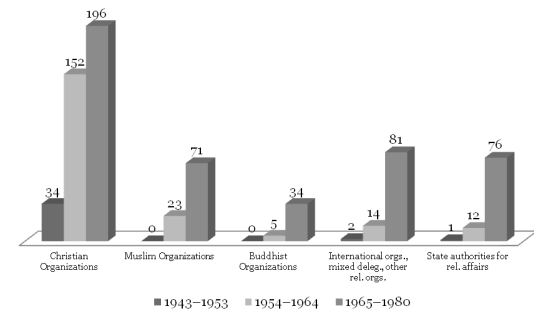


Appendices compiled from the files of the General Department of the CPSU Central Committee, 1945-1985: (a) A thematic file of the Apparat of the Central Committee of the CPSU (category: "VIII: Main departments and other organizations of the Council of Ministers of the USSR," subsections: "the Council for Religious Affairs," "the Council for Affairs of Religious Cults," "the Council for the Affairs of the Russian Orthodox Church); (b) A thematic file of the secretariat of the Central Committee of the CPSU (categories: "Anti-religious propaganda: Church," "Council for Religious Affairs," "Council for the Affairs of Religious Cults," "Council for the Affairs of the Russian Orthodox Church). Data have not been discovered for 1977, 1980, and 1981.

\section{References}

Rossiiskii gosudarstvennyi arkhiv noveishei istorii [Russian State Archive of Contemporary History] (RGANI), fond 3, opis' 60.

Akhmadulin, V. A. 2013a. "Deiatelnost' sovetskogo gosudarstva po privlecheniiu musul'man k bor'be za mir v 1940-kh-1950-kh gg." [The activities of the Soviet state to attract Muslims to the struggle for peace in 1940s-1950s]. Vlast 9: 121-24.

--_. 2013b. "Hadzh sovetskikh musul'man v 1953-1955 gg." [The Soviet Muslim hajj in 1953-1955]. Armiia i obshchestvo 3 (35): 88-92.

---. 2013c. "Hadzh sovetskikh musul'man v 1958-1959 [The hajj of Soviet Muslims in 1958-1959], Gumanitarnye i sotsial'no ekonomicheskie nauki 5: 50-54.

Chumachenko, T. A. 1999. Gosudarstvo, pravoslavnaia tserkov', veruiushchie, 19411961 gg. [The state, the Orthodox Church, believers, 1941-1961]. Moscow: AIRO-XX.

--_. 2007a. "Moskovskaia patriarkhiia v dvizhenii storonnikov mira: 1949-1953 gg." [The Moscow Patriarchate in the movement of the advocates for peace: 1949-1953]. Izvestiia Cheliabinskogo nauchnogo tsentra UrO RAN 1: 118-22.

---. 2007b. "V rusle vneshnei politiki sovetskogo gosudarstva: Moskovskaia patriarkhiia na mezhdunarodnoi arene v 1943-1948 gg." [Within the foreign policy of the Soviet state: The Moscow Patriarchate on the international scene in 1943-1948]. Vestnik Rossiiskogo universiteta druzhby narodov: Seriia Istoriia Rossii 1 (7): 89-99.

--_. 2008a. "'Soiuz tserkvei sotsialisticheskogo lageria': Sovet po delam RPTs i evoliutsiia vzaimootnoshenii Moskovskoi patriarkhii s pravoslavnymi tserkviami stran "narodnoi demokratii' v 1948-1953" ["The union of churches of the socialist camp": The Council for the Affairs of the ROC and the evolution of relations between the Moscow Patriarchate and the Orthodox churches of the countries of "people's democracy" in 1948-1953]. Vestnik Rossiiskogo universiteta druzhby narodov: Seriia Istoriia Rossii 1 (11): 67-81.

--_. 2008b. "Russkaia pravoslavnaia tserkov'v mezhdunarodnom dvizhenii storonnikov mira: Interesy tserkvi i vlasti (1949-1953)" [The Russian Orthodox Church in the international movement of advocates for peace: The interests of church and state (1949-1953)]. Magistra Vitae: Elektronnyi zhurnal po istoricheskim naukam $i$ arkheologii 5: 93-95.

---. 2010. "Sovet po delam RPTs i Moskovskaia patriarkhiia v reshenii vneshnepoliticheskikh zadach Khrushchevskogo rukovodstva: 1953-1958 gg." [The Council for the 
Affairs of the Russian Orthodox Church and the Moscow Patriarchate in the resolution of foreign policy problems of the Khrushchev leadership: 1953-1958]. Gosudarstvo, religiia, tserkov $v$ Rossii $i$ za rubezhom 4: 107-23.

--_. 2014. "V rusle vneshnei politiki stalinskogo rukovodstva: Russkaia pravoslavnaia tserkov' i patriarkhaty blizhnego vostoka, 1943-1953 gody" [Within the foreign policy of the Stalinist leadership: The Russian Orthodox Church and the patriarchates of the Middle East, 1943-1953]. Magistra Vitae: Elektronnyi zhurnal po istoricheskim naukam i arkheologii 22 (351): 142-48.

---. 2015a. "Moskovskaia patriarkhiia vo vneshnei politike sovetskogo pravitelstva: Interesy tserkvi, interesy vlasti, 1940-e-pervaia polovina 1960-kh gg." [The Moscow Patriarchate in the foreign policy of the Soviet government: The interests of the Church, the interests of the government, 1940s-first half of the 196os]. Svoboda sovesti $v$ Rossii: Istoricheskii i sovremennii aspekty, 11: 209-22.

--_. 2015b. "Otnosheniia Moskovskoi patriarkhii i vostochnikh patriarkhatov v kontekste evoliutsii blizhnevostochnoi politiki sovetskogo rukovodstva, 1953-1964 gody" [Relations of the Moscow Patriarchate and the Eastern Patriarchates in the context of the evolution of the Middle East policy of the Soviet leadership, 1953-1964]. Magistra Vitae: Elektronnii zhurnal po istoricheskim naukam i arheologii 2 (357): 117-22.

Danylets, Iu. V., and V. V. Mishchalkina. 2013. "Pravoslavna tserkva na Zakarpatti v umovakh stanovlennia Radians'koï vlady (1944-1950 rr.)" [The Orthodox Church in Transcarpathia in the formation of Soviet power (1944-1950)]. Rusyn 4: 88-112.

Egorova, I. I. 2005. "Vklad dvizheniia storonnikov mira v antiiadernye kampanii serediny 1950-x-nachala 1960-x gg." [The contribution of the advocates of peace to the anti-nuclear campaign of the mid-fifties to early sixties]. Elektronnyi nauchoobrazovatel'nyi zhurnal istoriia 2, p. 2.

Gorsuch, A. 2011. All This Is Your World: Soviet Tourism at Home and Abroad after Stalin. New York: Oxford University Press.

House, F. 1983. "A War-Time Visit to the Russian Church." Sobornost 5 (2): 46-55.

Iakunin, V. N. 2002a. "Mezhdunarodnaia deiatel'nost' Russkoi pravoslavnoi tserkvi v gody Velikoi Otechestvennoi voiny" [International activities of the Russian Orthodox Church during the Great Patriotic War]. Diplomaticheskii vestnik 10: 168-72.

---. 2002b. Vneshnie sviazi Moskovskoi patriarkhii i rasshirenie ee iurisdiktsii v gody Velikoi Otechestvennoi voiny 1941-1945 [External relations of the Moscow Patriarchate and the expansion of its jurisdiction in the years of the Great Patriotic War of 1941-1945]. Samara: Nauchno-tekhnicheskii tsentr.

Korol, V. L. 2013. "Mirotvorcheskaia deiatel'nost' Russkoi pravoslavnoi tserkvi (1949-1991): Istoriografiia problemy" [Peacekeeping activities of the Russian Orthodox Church (1949-1991): Historiography of the issue]. Vestnik Polotskogo gosudarstvennogo universiteta: Seriia A: Gumanitarnye nauki 9: 144-52.

Levchenko, I. V. 2001. Russkaia Pravoslavnaia Tserkov' i gosudarstvo [The Russian Orthodox Church and the state]. Irkutsk: Izd-vo IGEA.

Livtsov, V. A. 2000. Russkaia Pravoslavnaia Tserkov' i ekumenicheskoe dvizhenie $v$ XX veke [The Russian Orthodox Church and the ecumenical movement in the twentieth century]. Moscow.

---. 2008. "Ispol'zovanie ekumenizma v kachestve instrumenta sovetskoi vneshnei politiki v nachale 1960-kh godov" [The use of ecumenism as a tool of Soviet foreign policy in the early 1960s]. Izvestiia Rossiiskogo gosudarstvennogo pedagogicheskogo universiteta im. A. I. Gertsena 66: 223-29.

Maslova, I. I. 2005a. "Sovet po delam religii pri Sovete Ministrov SSSR i Russkaia pravoslavnaia tserkov' 1965-1991 gg.” [The Council for Religious Affairs under the USSR 
Council of Ministers and the Russian Orthodox Church (1965-1991)]. Rossiiskaia istoriia (Otechestvennaia istoriia) 6: 52-65.

---. 2005b. Sovetskoe gosudarstvo i Russkaia Pravoslavnaia Tserkov': Politika sderzhivaniia, 1964-1984 gg. [The Soviet state and the Russian Orthodox Church: The policy of deterrence (1964-1984)]. Moscow: MNEPU.

Murashko, G. P., and M. I. Odintsov, ed. 2003. Vlast' i tserkov'v SSSR i stranakh Vostochnoi Evropy, 1939-1958 [The authorities and the church in the USSR and the countries of Eastern Europe, 1939-1959]. Moscow: In-t slavianovedeniia RAN.

Odintsov, M. I. 1994. Gosudarstvo i tserkov'v Rossii: XX vek [State and Church in Russia: Twentieth century]. Moscow: Luch.

Orlov, I. B., and A. D. Popov. 2016. Skvoz' "zheleznyi zanaves": Russo turisto; Sovetskii vyezdnoi turizm, 1955-1991 [Through the "iron curtain": Russo turisto; Soviet outbound tourism from 1955 to 1991]. Moscow: Izd. Vysshei shkoly ekonomiki.

Petrov, S. V. 2014. "Evangelskie tserkvi vo vneshnepoliticheskom vektore religioznoi politiki SSSR v 1941-1948 gg." [The Evangelical churches in the foreign policy vector of religious politics in the USSR, 1941-1948]. Skhid 1 (127): 160-65.

Pospelovskii, D. V. 1995. Russkaia pravoslavnaia tserkov'v XX veke [The Russian Orthodox Church in the twentieth century]. Moscow: Respublika.

Sawatsky, W. 1981. Soviet Evangelicals since World War II. Kitchener, ON: Herald Press.

Shkuratov, I. V. 2005. "Sovetskoe gosudarstvo i vneshnepoliticheskaia deiatel'nost' Russkoi pravoslavnoi tserkvi (1945-1961 gg.)” [The Soviet state and foreign policy activity of the Russian Orthodox Church]. Kand. diss. Moscow State Regional University.

Vasileva, O. Iu. 2000."Vneshnaia politika sovetskogo gosudarstva i Russkaia pravoslavnaia tserkov', 1943-1948 gody" [The foreign policy of the Soviet state and the Russian Orthodox Church, 1943-1948]. Trudy Instituta rossiiskoi istorii RAN 2: 339-53.

---. 2004. Russkaia pravoslavnaia tserkov'i Vtoroi vatikanskii sobor [The Russian Orthodox Church and the Second Vatican Council]. Moscow: Lepta.

Veniamin (Gomarteli) and V. V. Tishagin. 200o. "Vysshee tserkovnoe upravlenie za granitsei" [The supreme ecclesiastical administration abroad]. Pravoslavnaia entsiklopediia, 10:106-8. Moscow: Tserkovno-nauchnyi tsentr "Pravoslavnaia entsiklopediia."

Volokitina, T. V. 2003. "Moskva i pravoslavnye avtokefalii Bolgarii, Rumynii i Iugoslavii (k probleme vospriiatiia sovetskoi modeli gosudarstvenno-tserkovnykh otnoshenii v 40-e gody XX veka)" [Moscow and the Orthodox autocephaly of Bulgaria, Romania and Yugoslavia (the problem of perception of the Soviet model of church-state relations in the forties of the twentieth century)]. In Vlast' $i$ tserkov' $v$ stranakh Vostochnoi Evropy, 1939-1958, edited by G. P. Murashko and V. I. Odintsov, 99125. Moscow: Institut slavianovedeniia RAN. 